Introduction

\title{
ISLANDS AND AQUAPELAGOS IN THE ANTHROPOCENE
}

[Received August 26th 2020; accepted August 30th 2020 - DOI: 10.21463/shima.14.2.03]

\author{
AMELIA MOORE \\ University of Rhode Island <ameliamoore@uri.edu>
}

\begin{abstract}
As many academics know by now, the Anthropocene has been generically defined as "the current geological age, viewed as the period during which human activity has been the dominant influence on climate and the environment" (Oxford Lexico, 2020: online). This definition has been roundly debated, expanded, and amended, and some scholars either deny the existence of such an age on technical grounds or argue for the renaming of the current age to more closely align with the ultimate causal forces driving all that anthropogenic activity. The most popular alternative terms for critical social scholars are now the Capitalocene and the Plantationocene (Moore, 2015; Haraway, 2015; Moore et al, 2019), however, the Anthropocene remains the most commonly used term, for better and for worse, and that is the language we will use in this themed section. Despite this nomenclature, all of the articles in this section describe events that stem from historical asymmetries of capital and deep structural inequity, processes that define the current age by any name.
\end{abstract}

Most scholarly research on the Anthropocene from the natural sciences elucidates specific biogeochemical effects of human activities on Earth. However, there is a growing body of work that examines the Anthropocene as a cultural phenomenon linking human and nonhuman processes through ever expanding networks of social and material interactivity. Within such Anthropocenic studies, there has been an increasing interest in islands and island infrastructures because islands are increasingly understood as iconic Anthropocene spaces (Moore, 2010; 2019). This collection takes up the examination of evolving island infrastructures in the Anthropocene (Larkin, 2013), recognising that 'islands' are not isolated terrestrial land masses and that island conditions are better understood as emergent within historical and contemporary processes of human and nonhuman interaction between the land and the sea and between other geographic systems, what Hayward (2012) has defined as an aquapelagic mode of being.

This section is therefore animated by an interest in the multiple ways that islands are being redesigned to connect to marine and coastal spaces. The authors all note in some shape or form that these designs are concerned with extending the networks and materialisations of the global tourism industry. As complex local relationships between humans and nonhumans are increasingly labelled 'anthropogenic impacts,' coastal, island, and marine tourism has been touted as a livelihood panacea for 'vulnerable' island regions, and spatial manipulation in the name of conservation and tourism development now rivals that of other extractive industries in some locales.

Shima <www.shimajournal.org> ISSN: 1834-6057 
In sum, this theme section provides examples from research at the intersection of Anthropocene studies, cultures of infrastructure, and tourism studies on islands and aquapelagos across the globe. Each article presents a critical engagement with island infrastructures in rapidly changing aquapelagic environments. Together, these articles demonstrate a form of collective "'thinking with islands' to understand contemporary phenomena with implications for other natural-cultural systems.

In 'Manufacturing Paradise on Catalina Island,' Kaytee Canfield describes the intentional constraint of historical aquapelagic relations in California's Channel Islands. She outlines the shift from an indigenous aquapelagic society and regional lives made between islands and the sea to the settler colonial, individuated 'paradise' tourist island, a formation that excludes even as it remakes infrastructural connections to the mainland and to populations of cheap labour. Private ferries, private housing, and private land conservation regimes now limit who and how visitors and residents experience the island. These infrastructures also materialise a virtualised escape from reality for many annual tourist arrivals. The result is an extremely limited aquapelagic system in which groups of people are simultaneously othered and forced to other themselves in a hierarchical island-based network of inequity.

Rennie Meyers', 'Art Islands,' explores the way in which recent events have led to a reimagined aquapelagic society via marine art installation infrastructure in the Canary Islands. Meyers details the history of César Manrique and his manipulation of the landscape of Lanzarote to fit his art island vision for sustainable tourism development, and she shows how the more recent Museo Atlántico attempts to extend that vision under water as a commentary on the Anthropocene. Meyers is in part enchanted by this artificial reef/art installation and in part critical of the way the Museo continues the commodification of the island's space, turning living processes into recreational objects and branding opportunities while inciting local conflict over space. Is this sustainable eco art that educates audiences about climate change and consumption or is this submerged art being used as an excuse to over develop the sea for outside interests?

In 'An Aquapelagic Evolution?', Adam Burke questions the conventional interpretation of historical events concerning ecotourism in the Galápagos. Taking a critical look at the entangled history of ecotourism and conservation in this island chain, he argues that the Galápagos National Park and Galápagos Marine Reserve merge conservation and tourism infrastructures in ways that marginalise Galápeguenos and extend cycles of colonial exploitation that began over 500 years ago. Burke reminds us that ecotourist infrastructures are also often infrastructures of economic leakage, the erasure of local knowledge, and systemic dependence, and he provides recommendations for more equitable aquapelagic relations.

Emanuela Borgnino's 'Mākua Valley', presents a call to indigenise an island place in response to histories of military and touristic (militourist) infrastructural restructuring in Hawai'i. Through an exploration of Kanaka Maoli land reclamation practices in the Mākua Valley of O'ahu, Borgnino discusses the history of violent aquapelagic dispossession on the island. She shows how the Kanaka Maoli sovereign assertions to redefine place reveal the entangled material and cultural consequences of settler colonialism and its roots in technologies and infrastructures of spatial accumulation, destruction, and reinvention. Borgnino concludes by offering a kind of solution in the notion that indigenous land reclamation practices might serve as a model for restructuring naturalcultural relations in the Anthropocene. 
Similarly to Borgnino, Jessica Vandenberg addresses much more recent concerns over potential dispossession in 'The Risk of Dispossession in the Aquapelago'. She describes the danger of unintentionally constraining aquapelagic socialities through the deployment of coral restoration infrastructure in the Spermonde Islands of Indonesia. Despite good intentions, the corporate led transformation of marine infrastructure in this small island system may be leading to forms of neocolonial dispossession for some island residents, disrupting place-based uses and relationships shared between community members on one island and between adjacent island communities. Local perceptions of such Anthropocene infrastructures give restoration technologies a material life that their designers never intended, and Vandenberg's work provides a lesson in small island social complexity and conservation responsibility.

In a short coda to the section, Iain Hall and Anne McDonald's 'The Abandoned Cars of Pohnpei' introduces abandoned fragments of infrastructure in the Federated States of Micronesia. Arguing that we can better understand challenges to small island life through failures of infrastructure across aquapelagic communities, Hall shows how the abandoned cars of Pohnpei materialise inequitable conditions. These wrecks may presage the future iconography of the Anthropocene even as they preclude any easy mythologising of the region as an Earthly paradise for tourist consumption. The authors lament this as an obstacle to economic sustainable development, but as the other articles in this theme issue help reveal, increased tourism and infrastructures of good intention often come at the expense of fully realised sovereign aquapelagic relations.

\section{BIBLIOGRAPHY:}

Haraway, D (2015) 'Anthropocene, Capitalocene, Plantationocene, Chthulucene: Making Kin', Environmental Humanities n6: 159-165

Hayward, P (2012) 'Aquapelagos and aquapelagic assemblages', Shima: The International Journal of Research into Island Cultures v6 n1: 1-11

Larkin, B (2013) 'The politics and poetics of infrastructure', Annual Review of Anthropology v42 n1: 327-343

Moore, A (2010) 'Climate changing small islands: considering social science and the production of island vulnerability and opportunity', Environment and Society: Advances in Research n1: 116-131

Moore, A (2019) Destination Anthropocene: science and tourism in The Bahamas, San Francisco: University of California Press

Moore, J (2015) Capitalism in the web of life: ecology and the accumulation of capital, New York: Verso Books

Moore, S.S, Allewaert, M, Gómez, P.F and Mitman. G (2019) 'Plantation legacies', Edge Effects January 22nd: https://edgeeffects.net/plantation-legacies-plantationocene/ - accessed August 25th 2020

Oxford/Lexico (2020) 'Anthropocene': https://www.lexico.com/definition/anthropocene - accessed 26th August 2020

Shima Volume 14 Number 22020 